\title{
Creative Process in the Design and Creation of Textile Manufacture
}

\author{
Sandra Helena da Siva de Santis* \\ University São Paulo, Brazil

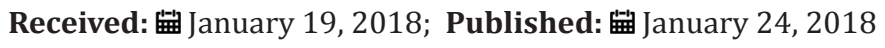 \\ *Corresponding author: Sandra Helena da Siva de Santis, University São Paulo, Brazil
}

\section{Introduction}

\section{Creative process}

Man has his creative manifestations through his individual aspirations, thoughts and idealization. The need is a motivating factor that drives the search for knowledge, problem solving and satisfaction, Santis [1]. For Lobach [2] "The conduct of the human being is also driven by multiple and varied needs. The emergence of needs is not always logical, especially when other activities or processes have occasional preference. "Necessity seeks satisfaction; aspiration is the spontaneous will to obtain something that comes from idea or visualization. The aspiration consists in the desire to obtain something that can be reached or not. Needs and aspirations accompany the evolution of technology, information tools and economic development. Lobach [2] states that design consists of a systematized design, plan or method that includes problem solving incorporating ideas, innovation, sketching, samples, models to make concrete the solution found.

Over the centuries, the needs in its evolution have been accompanied by the development of instruments, methods and systems. The constant evolution through research and events show that innovative creativity has played a key role. The development of the human creative process has also been marked by various frustrations, problems in creativity and with innovation; these problems are constantly reported by various scholars. Several researchers and researchers [2] have already been affected by creative inertia, difficulty in exposing ideas, fears, and lack of innovation or even problems that seemed unsolvable. Even so, the creative process has become an important tool for resource development. And the stimulation and organization of the creative process is being studied in theories, techniques and tools such as: Design Thinking, Design Methodology, and Inventive Problem Solving Theory. These are applied for the development of textile products.

\section{Product Development}

Ostrower [3] states that the ability to understand, assimilate, configure, and signify is the creative act. Creating is a way of establishing a new relationship between the human mind and the object in order to understand meaning or to redefine (giving a new meaning, a new practice, the ability to perceive an object through a different vision). Already the creative process derives from the structuring of cognition (knowledge of facts), intelligence (human characteristic composed of logical thinking, communication, knowledge, sensibility, problem solving, emotional control, etc.), creation ability (giving meaning to something or something) and innovation (creating something unknown). To meet the new type of consumer coming from social and communication changes, manufacturers seek to align existing needs with functionality and aesthetics by creating values that can be applied to technological fabrics.

Barbará [4] calls the process a set of ordered and integrated actions for a specific productive purpose that at the end of the cycle generate products, services or information. In the process of manufacturing with synthetic fibers began the decade of 30 , the developed fibers become part of the manufacture of fabrics and clothing. To give a small notion of what we call fiber, I find it interesting to contextualize the historical beginning, recalling some important facts. In this sense, the textile manufacturing manufacture uses the fibers to compose the yarn, and the woven yarn becomes fabric and various stamping and dyeing techniques. The textile production manufacture is divided into three cores: the yarn manufacturing, the fabric manufacture and the confection. According to Sanches [5] the fiber consists of the smallest element of the composition of the fabric in any natural or manufactured substance that has suitable characteristics that allow its processing. Being, the smallest component of hairy nature, which can be extracted or separated from a tissue. 
In wire manufacturing, the breeding process establishes the mixing of the materials for processing. The processing consists of a rational part that modifies the form of a structure or system for the construction of a mixture, an irrational part that is compounded by bringing together psychological, emotional, innovative, creative and personal aspects. This means that the transformation depends on the creative aspects to innovate in the fiber blend. The creation procedure promotes finding strategies that encourage the production of new means of mixing the components, which can motivate, add capacity and add value to the basic and secondary functions of the product or service to generate probabilities of more interactive information in the market, Santis [6]. The set of productive operations or manufacturing should have as main focus of improvement; increase in productivity and also in quality.

On an industrial scale (manufacturing sizing) in the contemporary, the good use of the methodology of the project presents some techniques that promote to encourage the application processes of the project methodology consist of the interaction of tools, resources and manpower converted into energy that perform the connection between procedures and tasks, Santis [1]. The manufacturing of textile the object of study of this research produces knitted fabric, working in the circular knitting industry, among its articles produced we can mention: knitwear for fitness, linings, beach and microfiber. Knitted textile manufactures that also serve as object for this research have a tradition in the Brazilian economy and, considered as one of the great s manufactured in Latin America, consisting of several business units in the country, its most common products made of fabric composed of combinations of polyamide, cotton and elastane (synthetic filament) in circular and straight looms.

Thus, actions constitute a form of processes that are interconnected in a physical or virtual structure, which establishes a set of ordered processes in operations to modify the resources in products. For Agostinho [7]. The fixation of the scripts and manufacturing processes fix the knowledge manufacturing, or how to do it, being considered the pillar of fixation of manufacturing knowledge. Following the scripts and manufacturing processes, it is determined the times required for each operation of the script, consequently of the parts and set of parts that make up the product [8-52].

Finally, the manufacturing and creative processes interrelate in a chain of interdependent functions, considering (external environment) and dependent variables (internal environment). This functional interrelationship facilitates the systematization of the production of goods and services. Each function has a sequential operation flow for the development of an operation from the inflow of resources to the exit of the goods or services. The set of actions in the creative process developed by a sequence of operations establishes the construction of a product, whether it is a consumer good or a service and this facilitates innovation in creative development.

\section{References}

1. M Sandra Helena Da Silva De Santis, Franco Giuseppe Dedini, Joao Paulo Pereira Marcicano, Regina Aparecida Sanches, Maria Silvia Barros De Hel, et al. (2016) Project Metodology Applyed to Smart Fabrics. Journal of Textile and Fashion 2: 7-17.

2. Lobach Bernd Design industrial: Bases para a configuração (2001) Rio de Janeiro: Edgard Blücher Ltd. Brazil.

3. Ostrower Fayga (1978) Criatividade e processos de criação.

4. Barbará, Saulo (2011) GestãoporProcessos. Rio de Janeiro: Qualitymark, Brazil.

5. Sanches Regina Ap, Aires Bárbara Santos, Aires Bruna Santos, Britto Renata Favari de, Panini Daiane Nacheset, et al. (2010) Tecnologiaaplicadanosartigos de vestuáriodestinados à prática de esportes.

6. Andra Helena Da Silva De Santis, Franco Giuseppe Dedini, João Paulo Pereira Marcicano, Regina Aparecida Sanches, Maria Sílvia Barros De Held, et al. (2017) Strategy of textile design: Use of design methodology tools in the creative process. Strategic Design Research Journal 10(1): 57-66.

7. Agostinho O L (2012) Sistemas de Manufatura, vol I e vol II, Apostilas de Curso, Universidade Estadual de Campinas.

8. Carvalho Marco Aurélio, M Eng, BACK Nelson (2001) Uso dos conceitosfundamentais da TRIZ e do método dos princípiosinventivos no desenvolvimento de produtos. In: CONGRESSO BRASILEIRO DE GESTÃO DE DESENVOLVIMENTO DE PRODUTO, Brazil.

9. Cross N (2006) Forty years of design research. Design Research Quarterly 1:3-5.

10. Chai K H, Zhang J, Tan K C (2005) A TRIZ-based method for new service design. Journal of Service Research 8(1): 48-66.

11. Da Silva Dailene Nogueira, Dos Santos Menezes (2013) Design Têxtil: Revisão Histórica, Surgimento E Evolução De Tecnologias.

12. Dallacosta A, souza-santos ED (2011) Economiacriativa:novasoportunidadesbaseadas no capital intelectual. Economia \&Tecnologia Curitiba ano: 7: 179-186.

13. Dedini F G (2007) Projeto de sistemas mecânicos. Apostila do curso EM 964 da Faculdade de EngenhariaMecânica da Unicamp, Engenharia Mecânica, Universidade Estadual de Campinas, Campinas,p. 179, Brazil.

14. Dos Santos Menezes Marizilda, Paschoarelli Luis Carlos (2009) Design e planejamento: aspectostecnológicos. UNESP, Brazil.

15. Ertas A, Jones J C (1996) The engineering design process. New York, Wiley, USA.

16. Gomes filho João (2004) Gestaltdoobjeto:Sistemadeleituravisualdaforma ed Escrituras, Brazil.

17. Gomide Fernando, Gudwin Ricardo R, Tanscheit Ricardo (1995) Conceitosfundamentais da teoria de conjuntos fuzzy, lógica fuzzy e aplicações. In: Proc 6th IFSA Congress- Tutorials p. 1-38.

18. GUO Wenchen, Xiao Hongjun, Yang Xi (2012) An empirical research on the correlation between human capital and career success of knowledge workers in enterprise. physics procedia 25: 715-725.

19. HITT MA, R Duane Ireland, Robert EH (2008) Administração Estratégica, CompetitividadeeGlobalização, SãoPaulo: Cengage Learning pp. 415.

20. Holborn, Mark (1995) Issey Miyake Verlag Alemanha: Taschen. Brazil.

21. Horrocks AR, Anand SC (2000) Handbook of Technical textiles, Boca Raton, The textile Institute CRC press, USA, pp. 358-381.

22. Hoskisson RE, MA Hitt (2009) EstratégiaCompetitiva. São Paulo: Cengage Learning p. 499. 
23. IEMI-Instituto de Estudos e Marketing Industrial S/C Ltd (2016) RelatórioSetorial da IndústriaTêxtilBrasileira. São Paulo: IEMI.

24. Jenkins Bryan R, Hine Philip T (2003) Benchmarking for best practice environmental management. Environmental monitoring and assessment 85(2): 115-134.

25. Jones, Sue Jenkin, tradução de IaraBiderman (2005) Fashion designmanual do estilista: Sue Jenkin Jones, São Paulo: CosacNaify pp. 240.

26. Jones Daniel T, Roos Daniel, James p Womack (1990) Machine that Changed the World. Simon and Schuster, UK.

27. Kalkan, Adnan, Özlem Çetinkaya Bozkurt, Mutlu Arman (2014) The impacts of intellectual capital, innovation and organizational strategy on firm performance." Procedia-Social and Behavioral Sciences 150: 700707.

28. Kucharčíková, Alžbeta; Tokarčíková Emese, Blašková Martina (2015) Human Capital Management-Aspect of the Human Capital Efficiency in University Education. Procedia-Social and Behavioral Sciences (177): 48-60.

29. Leonard Annie (2011) História das coisas: da naturezaaolixo, o que acontece com tudo que consumimos, Rio de Janeiro: Zahar.

30. Machado LFM,HeineckRL(2001) Modelos deproduçãoenxutadestinados à viabilização de vantagenscompetitiv as. ENEGEP, XXI, Brazil.

31. Martel Alain, Vieira Darli R (2008) Análise e projeto de RedesLogísticas. São Paulo: Ed Saraiva, Brazil.

32. Mesquita, Melissa (2001) Competênciaspara Melhoria Contínuada Produção: estudodecasoemempresas da indústria de autopeças. Dissertação (MestradoemEngenharia de Produção) - Universidade Federal de São Carlos, São Carlos, Brazil.

33. Mete, Fatma (2006) The creative role of sources of inspiration in clothing design". International Journal of Clothing Science and Technology 18(4): $278-293$.

34. Miles Lawrence D (1967) Value engineering. Verlag ModerneIndustrie, Brazil.

35. Morin Edgar (2011) Introduçãoao pensamento complexo. Porto Alegre: EditoraSulina OKABE, E. P. Metodologia de projeto para o desenvolvimento de suspensãoveicular (Doctoral dissertation, Dissertação de Mestradoapresentado à UniversidadeEstadual de Campinas-Faculdade de EngenhariaMecânica, Campinas.

36. Paladini Ep (2009) Gestãoestratégicadaqualidade-princípios,métodose processos ( $2^{\text {nd }}$ edn). São Paulo: Atlas, Brazil.

37. Pahl G, Beitz w (1996) Engineering design, a systematic approach,Springer, London.
38. Pahl G (2005) Projeto na Engenharia-Fundamentos do desenvolvimento, eficaz de produtos, métodos e aplicações. Tradução de Hans Andreas Werner São Paulo: Blucher, Brazil.

39. Paschoarelli, Luis Carlos, Dos Santos Menezes, Marizilda (2009) Design e ergonomia: aspectostecnológicos. UNESP, Brazil.

40. Pescuma Derna, Castilho, Antonio PF (2005) Projeto de pesquisa - o que é? Como fazer? Um guia para suaelaboração. São Paulo: Olhod Água, Brazil.

41. Pezzolo b Dinah (2007) Tecidos: Historia Trama, Tipos e Usos ( $1^{\text {st }}$ edn). São Paulo: SENAC, Brazil.

42. Rezende D A (2008) Planejamentoestratégico para organizaçõesprivadas e públicas. Brasport, Homgkong.

43. Rozenfeld h, forcelinni FA, Amaral DC, Toledo JC, De silva SL, Alliprandini DH, scalice r k (2006) Gestão de desenvolvimento de produtos: uma referência para a melhoria do processo. São Paulo: Saraiva, Brazil.

44. Roy, GoutamSahaDilip (2012) Designing office shirt: an integrated approach". Journal of Fashion Marketing and Management: An International Journal 16(3): 327-341.

45. Slack N (1999) Administração da Produção, Ed Atlas, São Paulo, Edição Compacta, Brazil

46. Smith RE (2011) Application of lean manufacturing tools in cash centres to improve operational efficiency. Tese deDoutorado.

47. Vasconcelos, Fernando Barros de (2012) Influência dos parâmetros de regulagem de máquinanascaracterísticasfísicas de malhas de poliamida/ elastano. Tese de Doutorado. Universidade de São Paulo pp. 163.

48. Vergara Sylvia Constant (1998) Projetoserelatóriosdepesquisaemadministração (2 ${ }^{\text {nd }}$ edn). São Paulo: Atlas. Brazil.

49. Vianna Claudia, Quaresma, Manuela (2015) Ergonomia: conforto têxtil no Vestuário do idoso. Blucher Design Proceedings 2: 1662-1670.

50. Vicentini Claudia Regina Garcia (2010) Ferramentas e metodologia de projetoaplicados na criação de produtos para a indústriatêxtil-confecção. Tese de Doutorado. Tese dedoutoradoapresentado à Universidade Estadual de Campinas-Faculdade de EngenhariaMecânica, Campinas.

51. Xuan Liu, Minglu Zhang, Wei Liu, Lina Fan (2009) Modular Robot System Configuration Design Based on Axiomatic Design. Proceeding of the IEEE International Conference on Automation and Logistics.

52. Saville B P (1999) Physical testing of textiles. Elsevier.

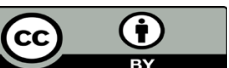

This work is licensed under Creative Commons Attribution 4.0 License

Submission Link:

Submit Article

DOI: $10.32474 /$ LTTFD.2018.01.000109

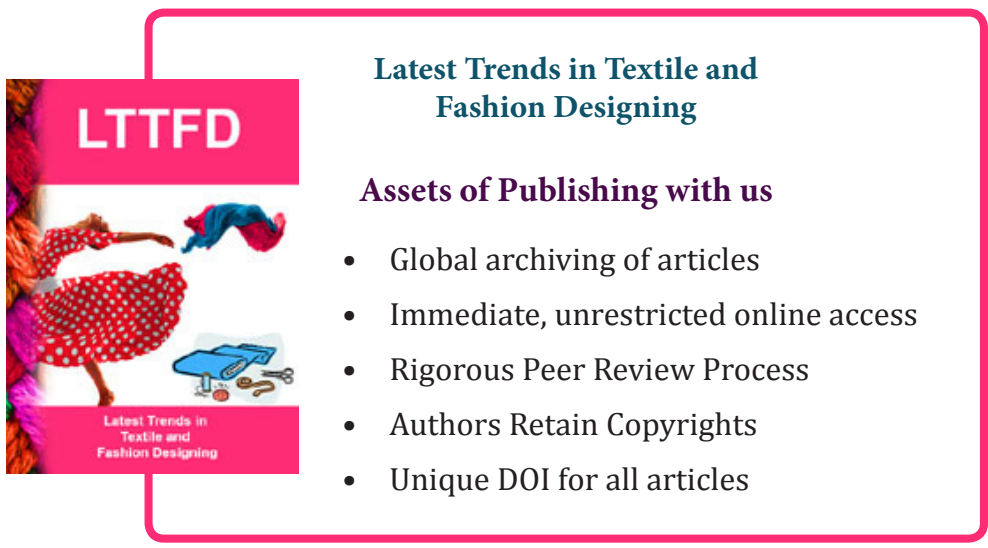

